\title{
PENGARUH SISTEM PENGENDALIAN INTERN TERHADAP PENYUSUNAN RENCANA KERJA DAN ANGGARAN (RKA) PADA BADAN PERENCANAAN PEMBANGUNAN DAERAH (BAPPEDA) KOTA BANDUNG
}

\author{
Saiful Almujab \\ Email: saifulalmujab@unpas.ac.id \\ Universitas Pasundan
}

\begin{abstract}
ABSTRAK
Penalitian ini bertujuan untuk mengukur seberapa besar pengaruh sistem pengendalian intern terhadap penyusunan Rencana Kerja dan Anggaran (RKA). Sistem pengendalian intern yang dijabarkan dalam penelitian meliputi struktur organisasi, metode dan ukuran-ukuran yang dikoordinasikan untuk menjaga kekayan organisasi, mengecek ketelitian dan keandalan data akuntansi, mendorong efisiensi dan mendorong dipatuhinya kebijakan manajemen. Sedangkan rencana kerja dan anggaran adalah dokumen perencanaan dan pengangaran yang berisi rencana pendapatan, rencana belanja program dan kegiatan SKPD serta rencana pembiayaan sebagai dasar penyusunan APBN. Hasil penelitian menunjukan terdapat korelasi yang positif dalam kategori kuat sedangkan pengaruh sistem pengendalian intern terhadap penyusunan Rencana Kerja dan Anggaran (RKA) pada Badan Perencanaan Pembangunan Daerah (BAPPEDA) Kota Bandung sebesar 82\% dan 18\% dipengaruhi oleh faktor lain yang penulis tidak teliti. Nilai regresi penelitian menunjukan $Y=4,40+0,81 X$, dengan koefisien determinasi 0,82.
\end{abstract}

Kata Kunci: Sistem Pengendalian Intern; Rencana Kerja dan Anggaran

\begin{abstract}
This analysis aims to measure how much influence the internal control system has on the preparation of the Work Plan and Budget (RKA). The internal control system described in the study includes the organizational structure, methods and measures that are coordinated to maintain organizational wealth, check the accuracy and reliability of accounting data, encourage efficiency and encourage compliance with management policies. Whereas work plans and budgets are planning and budgeting documents containing revenue plans, program expenditure plans and SKPD activities and financing plans as the basis for preparing the $A P B N$. The results showed that there was a positive correlation in the strong category while the effect of the internal control system on the preparation of Work Plans and Budgets (RKA) in the Bandung Regional Development Planning Agency (BAPPEDA) was $82 \%$ and $18 \%$ was influenced by other factors which the authors did not examine. The regression value of the study showed $Y=4.40+0.81 X$, with a coefficient of determination of 0.82 .
\end{abstract}

Keywords: Internal Control System; Work Plan and Budget

\section{PENDAHULUAN}

Sistem pengendalian intern merupakan hal yang sangat penting untuk dilakukan sehingga pada umumnya setiap lembaga baik pemerintah maupun swasta perlu adanya sistem pengendalian intern. Pada pemerintahan daerah sejak tahun 1999 berdasarkan Undang-Undang Nomor 23 Tahun 2004 tentang pemerintah daerah dan Undang-Undang Nomor 33 Tahun 2004 tentang perimbangan keuangan antara pemerintah pusat dan daerah setiap daerah diberikan kewenangan untuk mengelola pemerintahanya yang disebut otonomi daerah.

Sejalan dengan hal tersebut baik pemerintah pusat, provinsi, kabupaten maupun kota membentuk lembaga yang bertugas untuk perencanaan pembanguan bagi daerahnya yang 
di sebut Badan Perencanaan Pembanguan Daerah (BAPPEDA). Untuk melaksankan tugasnya sebagai perencana pembanguan daaerah tentunya perlu menyusun anggaran yang dipergunakan untuk kegiatan operasionalnya.

Salah satu tugas dari Badan Perencanaan Pembangunan Daerah (BAPPEDA) yaitu menyusun perencanaan strategis bagi dinas pendidikan untuk dapat memfasilitasi proses pembelajaran yang diharapkan mampu menghasilkan peserta didik yang berkualitas. Salah satu cara untuk meningkatkan kualitas peserta didik yaitu dengan menggunakan pendekatan PAIKEM (Pembelajaran Aktif, Inovatif, Kreatif, Efektif dan Menyenangkan).

Hasil observasi yang peneliti lakukan pada Badan Perencanan Pembangunan Daerah (BAPPEDA) Kota Bandung, peneliti menemukan bahwa dalam kegiatan penyusunan anggaran di sub bagian program yang di himpun oleh kepala sub bidang program terlalu banyak program yang diusulkan sehingga anggaran yang ada tidak cukup untuk memenuhi semua usulan tersebut dan standar dalam penetapan harga dalam usulan anggaran tidak sesuai dengan pelaksanaan dikarenakan proses penyusunan anggaran dilakukan pada tahun sebelumnya sementara untuk pelaksanaan pada tahun yang akan datang.

Karena pada umumnya setiap instansi pemerintah akan menemukan berbagai masalah yang kompleks dengan karakteristik yang berbeda sesuai dengan besar kecilnya program yang harus dilaksanakan yang selaras dengan rencana strategis pemerintah daerah maupun pemerintah pusat. Dengan semakin berkembangnya pemikiran dan peran serta masyarakat dalam proses pembangunan daerah sehingga menuntut adanya kesesuaian anggaran yang digunakan dengan program yang dilaksanakan, sehingga pada akhirnya akan semakin luas dan semakin kompleks pula sistem pengendalian intern yang digunakan untuk penyusunan Rencana Kerja dan Anggaran (RKA) di dalam Satuan Kerja Perangkat Dinas (SKPD) di setiap instansi pemerintah daerah.

Berdasarkan hal di atas untuk membantu dalam melakukan aktifitas di dalam instansi pemerintah daerah diperlukan sistem pengendalian intern yang baik sehingga efektivitas anggaran tercapai sesuai dengan tujuan yang direncanakan dalam rencanan strategis pemerintah daerah serta selaras dengan keinginan masyarakat.

Sistem pengendalian intern merupakan suatu kegiatan yang meliputi analisa, penelaahan dan penelitian yang dilakukan terhadap kebijaksanaan, prosedur, metode dan pelaksanaan kegiatan yang akan menunjang kepada tercapainya penyusunan anggaran. Sedangkan anggaran dapat dikatakan sebagai pedoman kerja dan memberikan arah sekaligus memberikan target yang harus dicapai oleh kegiatan yang akan dilaksanakan pada waktu yang akan datang dan dapat dijadikan suatu pengukuran kinerja.

Apabila sistem pengendalian intern sesuai dengan apa yang diharapkan maka dapat meminimalkan penyimpangan saat meyusunan anggaran. Untuk itu, perlu diteliti sejauh mana sistem pengendalian intern berpengaruh terhadap penyusunan Rencana Kerja dan Anggaran (RKA) pada Badan Perencanaan Pembangunan Daerah (BAPPEDA) Kota Bandung.

\section{TINJAUAN PUSTAKA}

\section{Sistem Pengendalian Intern}

Sistem pengendalian intern pada dasarnya diperlukan dalam suatu perusahaaan atau instansi pemerintahan sebagai alat bantu manajemen, terutama pimpinan untuk mengawasi setiap tahap kegiatan perusahaanya. Keadaan tersebut timbul sebagai akibat ruang lingkup pengawasan (span of control) yang menjadi tugasnya semakin luas dan tidak mungkin dilakukannya sendiri. Terciptanya sistem pengendalian intern dimaksudkan, agar masalah yang timbul oleh faktor manusia baik yang disengaja atau tidak dapat ditekan sekecil mungkin. menurut AICPA dalam Barry (2003: 78) sistem pengendalian intern (internal control) meliputi rencana organisasi dan semua metode yang terkoordinir dan tindakan/ ukuran yang ditetapkan dalam suatu perusahaan adalah mengamankan harta (kekayaan) nya, memiliki ketelitian dan keandalan data akuntansi, meningkatkan efisiensi operasi dan mendorong ketaatan terhadap kebijakan yang diterapkan oleh manajemen 
Aktivitas pengendalian intern tidak lepas dari proses bagaimana tujuan itu direncanakan sehingga yang pada akhirnya akan mempengaruhi pada pelaksaaan dan hasil yang diharapkan setelah dilaksanakanya sistem pengendalian intern. Menurut Mulyadi (2001:163) tujuan sistem pengendalian intern adalah sebagai berikut:

1. Menjaga kekayaan organisasi

2. Mengecek ketelitian dan keandalan data akuntansi

3. Mendorong efisiensi

4. Mendorong dipatuhinya kebijakan manajemen

Selanjutnya, Mulyadi (2001:163-164) menjelaskan bahwa tujuan, sistem pengendalian intern dibagi menjadi dua (2) macam yaitu:

1. Pengendalian intern akuntansi (internal accounting control), merupakan bagian dari sistem pengendalian intern, meliputi struktur organisasi, metode dan ukuran-ukuran yang dikoordinasikan terutama untuk menjaga kekayaan organisasi dan mengecek ketelitian dan keandalan data akuntansi.

2. Pengendalian intern administratif (internal administrative control), meliputi struktur organisasi, metode dan ukuran-ukuran yang dikoordinasikan terutama untuk mendorong efisiensi dan dipatuhinya kebijakan manajemen, yang secara langsung berhubungan dengan catatan finansial yang pada umumnya meliputi pengendalianpengendalian seperti analisa statistik, program latihan pegawai dan pengendalian kualitas.

Agar dapat mencapai tujuan sistem pengendalian intern, maka diperhatikan unsur-unsur yang terkandung dalam sistem pengendalian intern tersebut. Menurut Mulyadi (2001:164) unsur pokok sisitem pengendalian intern adalah:

1. Struktur organisasi yang memisahkan tanggungjawab fungsional secara tegas.

2. Sistem wewenang dan prosedur pencatatan yang memberikan perlindungan yang cukup terhadap kekayaan, utang, pendapatan dan biaya.

3. Praktik yang sehat dalam melaksanakan tugas dan fungsi setiap unit organisasi.

4. Karyawan yang mutunya sesuai dengan tanggung jawabnya.

Manajemen bertanggung jawab untuk menyusun, melaksanakan dan mengawasi berjalannya sistem pengendalian intern. Sistem apapun pada dasarnya baik, namun tidak sepenuhnya dapat mengatasi penyelewengan dan kesalahan pencatatan karena adanya keterbatasan-keterbatasan yang ada pada sistem pengendalian intern tersebut.

Seperti yang dikemukakan oleh Mulyadi dan Kanaka Puradiredja (2005:172-173) mengatakan ada beberapa faktor yang memperlemah sistem pengendalian intern adalah sebagai berikut:

1. Kesalahan dalam pertimbangan

2. Gangguan

3. Kolusi.

4. Pengabaian oleh manajemen

5. Biaya lawan manfaat

\section{Rencana Keja dan Anggaran}

Menurut Indra Bastian (2006:163) anggaran adalah sebagai paket pernyataan perkiraan penerimaan dan pengeluaran yang diharapkan akan terjadi dalam satu atau beberapa periode mendatang.

Penyusunan anggaran berdasarkan suatu struktur dan klasifikasi tertentu adalah suatu langkah penting untuk mendapatkan sistem penganggaran yang baik. Sejalan dengan hal tersebut anggaran di buat untuk membantu menentukan tingkat kehidupan mayarakat, seperti listrik, air bersih, kualitas kesehatan, pendidikan, dan sebagainya agar terjamin secara layak.

Aliran uang yang terkait dengan aktivitas pemerintah akan mempengaruhi harga, lapangan kerja, distribusi pendapatan, pertumbuhan ekonomi, dan beban pajak yang harus dibayar atas pelayanan yang diberikan pemerintah. Keputusan anggaran yang dibuat pemerintah daerah dan provinsi seharusnya dapat merefleksikan prioritas pemerintah daerah dan provinsi dengan baik. Menurut Mardiasmo (2005:63) Anggaran menjadi hal penting karena beberapa alasan yaitu: 
1. Anggaran merupakan alat bagi pemerintah untuk mengarahkan pembangunan sosialekonomi, menjamin kesinambungan, dan meningkatkan kualitas hidup masyarakat.

2. Anggaran diperlukan karena adanya kebutuhan dan keinginan masyarakat yang tak terbatas dan terus berkembang, sedangkan sumberdaya yang ada terbatas. Anggaran diperlukan karena adanya masalah keterbatasan sumber daya (scarcity of resources), pilihan (choice), dan trade offs.

3. Anggaran diperlukan untuk meyakinkan bahwa pemerintah telah bertanggungjawab terhadap rakyat. Dalam hal ini anggaran merupakan instrumen pelaksanaan akuntabilitas publik oleh lembaga-lembaga publik yang ada.

Anggaran dalam sebuah perusahaan maupun instansi pemerintahan mempunyai peranan yang sangat penting bagi aktivitas perusahaan dan instansi pemerintahan. Menurut Indra Bastian (2006:166-177) anggaran terdiri dari:

1. Line Item Budgeting

2. Incremental Budgeting

3. Planning Programing Budgeting system (PPBS)

4. Zero Based Budgeting (ZBB)

5. Performance Budgeting

6. Medium Term Budgeting Framework (MTBF)

Mencapai anggaran yang efektif dan efisien merupakan harapan bagi semua pelaksana anggaran baik yang berada di perusahaan maupun instansi pemerintahan oleh sebab itu, diterapkan suatu prinsip untuk menjadikan anggaran tersebut sesuai dengan apa yang diharapkan. Prinsip-prinsip penganggaran yang dikemukakan oleh Guntur Simanjuntak dkk (2005:37-38) antara lain:

1. Transparansi dan Akuntabilitas Anggaran

APBD harus dapat menyajikan informasi yang jelas mengenai tujuan, sasaran, hasil, dan manfaat yang diperoleh masyarakat dari suatu kegiatan atau proyek yang dianggarkan. Anggota masyarakat memiliki hak dan akses yang sama untuk mengetahui proses anggaran karena menyangkut aspirasi dan kepentingan masyarakat, terutama pemenuhan kebutuhan-kebutuhan hidup masyarakat. Masyarakat juga berhak untuk menuntut pertanggungjawaban atas rencana ataupun pelaksanaan anggaran tersebut.

2. Disiplin Anggaran

Pendapatan yang direncanakan merupakan perkiraan yang terukur secara rasional yang dapat dicapai untuk setiap sumber pendapatan, sedangkan belanja yang dianggarkan pada setiap pos/pasal merupakan batas tertinggi pengeluaran belanja. Penganggaran pengeluaran harus didukung dengan adanya kepastian tersedianya penerimaan dalam jumlah yang cukup dan tidak dibenarkan melaksanakan kegiatan/proyek yang belum/tidak tersedia anggarannya dalam APBD/perubahan APBD.

3. Keadilan Anggaran

Pemerintah daerah wajib mengalokasikan penggunaan anggarannya secara adil agar dapat dinikmati oleh seluruh kelompok masyarakat tanpa diskriminasi dalam pemberian pelayanan karena pendapatan daerah pada hakekatnya diperoleh melalui peran serta masyarakat.

4. Efisiensi dan Efektifitas Anggaran

Penyusunan anggaran hendaknya dilakukan berlandaskan azas efisiensi, tepat guna, tepat waktu pelaksanaan, dan penggunaannya dapat dipertanggungjawabkan. Dana yang tersedia harus dimanfaatkan dengan sebaik mungkin untuk dapat menghasilkan peningkatan dan kesejahteraan yang maksimal untuk kepentingan masyarakat.

5. Disusun dengan Pendekatan Kinerja

APBD disusun dengan pendekatan kinerja, yaitu mengutamakan upaya pencapaian hasil kerja (output/outcome) dari perencanaan alokasi biaya atau input yang telah ditetapkan. Hasil kerjanya harus sepadan atau lebih besar dari biaya atau input yang 
telah ditetapkan, selain itu harus mampu menumbuhkan profesionalisme kerja di setiap organisasi kerja yang terkait.

\section{METODE PENELITIAN}

Metode penelitian yang digunakan dalam penelitian ini adalah metode penelitian survey dengan tingkat ekplanasi asosiatif kausal. Metode penelitian survey dengan tingkat explanasi asosiatif kausal merupakan metode penelitian yang menggunakan perlakuan dari peneliti dan mencari hubungan antar suatu variabel dengan variabel lainnya dimana hubungan tersebut bersifat sebab akibat yaitu variabel yang satu menjadi sebab dan dapat menjadi akibat terhadap variabel lainnya.

Populasi yang digunakan sebagai objek penelitian adalah karyawan atau pegawai Badan Perencanaan Pembangunan Daerah (BAPPEDA) Kota Bandung khususnya yang berhubungan dan yang melaksanakan sistem pengendalian intern dan penyusunan Rencana Kerja dan Anggaran (RKA). Sedangkan, teknik pengumpulan data dalam penelitian ini dilakukan dengan angket (kuesioner), penelitian lapangan (Field Research) dan penelitian kepustakaan (Library Research).

\section{HASIL DAN PEMBAHASAN}

\section{Uji Hipotesis}

Sebelum penulis melakukan uji hipotesis maka terlebih dahulu penulis mengajukan hipotesis statistik yang akan diuji dalam penelitian ini. Berikut ini merupakan hipotesis statistik yang penulis ajukan.

Ho: $\rho=0=$ tidak terdapat pengaruh sistem pengendalian intern yang dijalankan sesuai prosedur terhadap penyusunan Rencana Kerja dan Anggaran (RKA) pada Badan Perencanaan Pembangunan Daerah (BAPPEDA) Kota Bandung.

Ha: $\rho \neq 0=$ terdapat pengaruh sistem pengendalian intern yang dijalankan sesuai prosedur terhadap penyusunan Rencana Kerja dan Anggaran (RKA) pada Badan Perencanaan Pembangunan Daerah (BAPPEDA) Kota Bandung.

Berdasarkan hipotesis tersebut penulis melakukan uji hipotesis dan melakukan pengujian dengan langkah-langkah tertentu. Adapun langkah-langkah yang diambil adalah sebagai berikut:

Tabel 1

Tabel Penolong Untuk Menghitung Korelasi Spearman Rank Variabel $X$ dan Variabel $Y$

\begin{tabular}{ccccccc}
\hline $\begin{array}{c}\text { No } \\
\text { Res }\end{array}$ & $\mathbf{X}$ & $\mathbf{Y}$ & $\begin{array}{c}\text { Rangking } \\
(\mathbf{X})\end{array}$ & $\begin{array}{c}\text { Rangking } \\
(\mathbf{Y})\end{array}$ & $\begin{array}{c}\mathbf{X}-\mathbf{Y} \\
\left(\mathbf{b}^{\mathbf{i}}\right)\end{array}$ & $\mathbf{b}_{\mathbf{i}}{ }^{2}$ \\
\hline 1 & 73 & 66 & 1 & 1,5 & $-0,5$ & 0,25 \\
2 & 69 & 64 & 4 & 3 & 1 & 1 \\
3 & 60 & 54 & 8 & 6 & 2 & 4 \\
4 & 56 & 49 & 9 & 8,5 & 0,5 & 0,25 \\
5 & 71 & 59 & 3 & 4 & -1 & 1 \\
6 & 72 & 66 & 2 & 1,5 & 0,5 & 0,25 \\
7 & 50 & 49 & 10 & 8,5 & 1,5 & 2,25 \\
8 & 62 & 46 & 5 & 10 & -5 & 25 \\
9 & 61 & 53 & 6,5 & 7 & $-0,5$ & 0,25 \\
10 & 61 & 57 & 6,5 & 5 & 1,5 & 2,25 \\
\hline Jumlah & - & - & - & - & $\mathbf{0}$ & $\mathbf{3 6 , 5}$ \\
\hline
\end{tabular}

\section{Analisis Regresi}

Analisis regresi digunakan untuk mengetahui bagaimana variabel dependen dapat diprediksikan melalui variabel independen secara individual. 
Tabel 2

Tabel Penolong Untuk Menghitung Regresi

Variabel $X$ dan Variabel $Y$

\begin{tabular}{cccccc}
\hline $\begin{array}{c}\text { No } \\
\text { Res }\end{array}$ & $\mathbf{X}$ & $\mathbf{Y}$ & $\mathbf{X Y}$ & $\mathbf{X}^{2}$ & $\mathbf{Y}^{\mathbf{2}}$ \\
\hline 1 & 73 & 66 & 4.818 & 5.329 & 4.356 \\
2 & 69 & 64 & 4.416 & 4.761 & 4.096 \\
3 & 60 & 54 & 3.240 & 3.600 & 2.916 \\
4 & 56 & 49 & 2.744 & 3.136 & 2.401 \\
5 & 71 & 59 & 4.189 & 5.041 & 3.481 \\
6 & 72 & 66 & 4.752 & 5.184 & 4.356 \\
7 & 50 & 49 & 2.450 & 2.500 & 2.401 \\
8 & 62 & 46 & 2.852 & 3.844 & 2.116 \\
9 & 61 & 53 & 3.233 & 3.721 & 2.809 \\
10 & 61 & 57 & 3.477 & 3.721 & 3.249 \\
\hline Jumlah & $\mathbf{6 3 5}$ & $\mathbf{5 6 3}$ & $\mathbf{3 6 . 1 7 1}$ & $\mathbf{4 0 . 8 3 7}$ & $\mathbf{3 2 . 1 8 1}$ \\
\hline
\end{tabular}

Persamaan Regresi $Y=a+b X$

$$
\begin{aligned}
& a=\frac{\left(\sum y_{1}\right)\left(\sum x_{1}^{2}\right)-\left(\sum x_{1}\right)\left(\sum x_{1} y_{1}\right)}{n \sum x_{1}^{2}-\left(\sum x_{1}\right)^{2}} \\
& a=\frac{(563)(40.837)-(635)(36.171)}{10(40.837)-(403.225)} \\
& a=\frac{22.646}{5.145} \\
& a=4,40
\end{aligned}
$$

Sedangkan nilai $b$ adalah:

$$
\begin{aligned}
& b=\frac{n \sum x_{1} y_{1}-\left(\sum x_{1}\right)\left(\sum y_{1}\right)}{n \sum x_{1}^{2}-\left(\sum x_{1}\right)^{2}} \\
& b=\frac{10(36.171)-(635)(563)}{10(40.837)-(403.225)} \\
& b=\frac{4.205}{5.145} \\
& b=0,81
\end{aligned}
$$

Berdasarkan hasil perhitungan di atas, menggambarkan perhitungan regresi sederhana $Y=4,40+0,81 X$ dimana $Y$ adalah Rencana Kerja dan Anggaran (RKA) dan $X$ adalah sistem pengendalian intern. Persamaan mengindikasikan setiap kenaikan sistem pengendalian intern akan memberikan kenaikan pula pada penyusunan Rencana Kerja dan Anggaran (RKA)

\section{Uji Besar Pengaruh / Koefisien Determinasi}

Uji besar pengaruh merupakan perhitungan untuk menentukan berapa persen pengaruh sistem pengendalian intern terhadap penyusunan Rencana Kerja dan Anggaran (RKA) dapat diketahui dengan rumus: 


$$
\begin{aligned}
R^{2} & =\frac{b^{2} \cdot \Sigma x^{2}}{\Sigma y^{2}} \\
& =\frac{0,65 \cdot 40 \cdot 837}{32 \cdot 181} \\
& =\frac{26.544}{32.181} \\
& =0,82 \text { atau } 82 \%
\end{aligned}
$$

Berdasarkan hasil perhitungan di atas, akhirnya penulis menyimpulkan bahwa sistem pengendalian intern mempunyai pengaruh positif dan signifikan terhadap penyusunan Rencana Kerja dan Anggaran (RKA) sebesar $82 \%$ dan sisanya sebesar $18 \%$ dipengaruhi oleh faktor lain, yang tidak diteliti oleh penulis.

\section{Uji signifikansi}

Uji signifikansi dilakukan untuk memperoleh perhitungan terbukti atau tidaknya hipotesis yang penulis ajukan, maka dilakukan uji signifikansi yang mana hasilnya adalah sebagai berikut:

$$
\begin{aligned}
t & =\frac{r \sqrt{n-2}}{\sqrt{1-r^{2}}} \\
& =\frac{0,78(2,28)}{\sqrt{1-(0,60)}} \\
& =\frac{1,7784}{0,6324} \\
& =2,812
\end{aligned}
$$

Harga thitung tersebut selanjutnya dibandingkan dengan harga $t_{\text {tabel. }}$ Untuk taraf kesalahan $5 \%$ atau 0,05 dengan uji satu fihak dan derajat ketepatan (dk), dk =n - $2=10-2$ $=8$, maka diperoleh $t_{\text {tabel }}$ adalah 1,860. Berdasarkan perolehan perhitungan diatas dapat diketahui bahwa hasil dari thitung adalah 2,812 dan jika dibandingkan dengan besaran perhitungan $t_{\text {tabel }}$ adalah 1,860 sehingga dapat disimpulkan $t_{2,812}>t_{1,860}$ yang artinya bahwa hipotesis yang penulis ajukan terbukti.

Hasil penelitian secara keseluruhan dapat diketahui bahwa nilai dari hasil perhitungan regresi diperoleh $a=4,40$ sedangkan $b=0,81$, maka persamaan regresinya adalah $Y=4,40$ $+0,81 \mathrm{X}$, untuk perhitungan korelasi di dapatkan nilai koefisien korelasi sebesar 0,78 hal tersebut menunjukan korelasi yang kuat.

Koefisien determinasi digunakan untuk mencari tingkat pengaruh antara sistem pengendalian intern terhadap penyusunan Rencana Kerja dan Anggaran (RKA) yang hasilnya sebesar $82 \%$. Hal ini menunjukan antara variabel bebas sistem pengendalian intern dengan variabel terikat yaitu Rencana Kerja dan Anggaran (RKA) mempunyai pengaruh sebesar $82 \%$ sedangkan $18 \%$ dipengaruhi oleh faktor lain.

Sistem pengendalian interen yang dilaksanakan oleh Badan Perencanaan Pembangunan Daerah (BAPPEDA) Kota Bandung telah memadai, dengan adanya peraturan Menteri Dalam Negeri Nomor 13 Tentang Pengelolaan Keuangan Daerah, dan untuk intern dalam organisasi BAPPEDA sendiri telah diatur melalui PERDA Kota Bandung Nomor 12 Tahun 2009 tentang struktur organisasi Badan Perencanaan Pembangunan Daerah (BAPPEDA) Kota Bandung serta untuk job description diatur dalam Peraturan Walikota (PERWALKOT) Nomor 474 tahun 2008, sejalan dengan hal tersebut untuk proses 
penyusunan dan evaluasi dari Rencana Kerja dan Anggaran (RKA) diatur dalam Peraturan Walikota (PERWALKOT) Nomor 121 Tahun 2010 Tentang Tata Cara Pengendalian dan Evaluasi Pelaksanaan Pembangunan Daerah Serta Pedoman dan Tata Cara Musyawarah Perencanaan Pembangunan Daerah.

Berdasarkan hal di atas dapat disimpulkan bahwa terdapat pengaruh yang positif sistem pengendalian intern terhadap penyusunan Rencana Kerja dan Anggaran (RKA) sebesar $82 \%$ yang dipengaruhi oleh unsur sistem pengendalian intern sebagai berikut:

1. Adanya struktur organisasi yang memisahkan tanggungjawab dan wewenang.

Struktur organisasi merupakan aspek penting dalam sebuah organisasi karena di dalam struktur organisasi terlihat adanya pemisahaan tanggungjawab secara tegas di Badan Perencanaan Pembangunan Daerah (BAPPEDA) Kota Bandung. Tujuan pokok pemisahan tanggung jawab ini adalah untuk mencegah dan dapat mendeteksi secepat mungkin atas kesalahan dan kelalaian dalam pelaksanaan tugas yang dibebankan kepada seseorang.

2. Adanya sistem wewenang dan prosedur pencatatan.

Sistem pemberian wewenang pada suatu sistem merupakan pelimpahan wewenang secara penuh kepada bagian dalam struktur organisasi instansi sesuai dengan lingkup kerjanya. Sedangkan prosedur pencatatan ditujukan untuk mengendalikan harta, utang, pendapatan serta biaya. Pencatatan dan penggunaan formulir dalam penyusunan anggaran memberikan efek yang besar dalam sistem pengendalian intern yang telah dijalankan.

3. Praktek yang sehat dalam melaksanakan tugas dan fungsi organisasi.

Praktek yang sehat adalah pelaksanaan manajemen yang menerapkan prosedur yang sistematis. Penerapan prosedur yang sistematis ini dimaksudkan untuk mempermudah pengawasan dalam kegiatan manajemen instansi pemerintahan. Adanya praktek yang sehat diharapkan sistem dan prosedur yang telah ditetapkan dapat di taati sehingga menghindari penyelewengan yang mungkin saja terjadi dalam suatu instansi pemerintahan. Praktek yang sehat dalam menerapkan prosedur yang sistematis yaitu pengambilan cuti pegawai dan adanya perputaran jabatan.

4. Pegawai yang kualitasnya sesuai tanggung jawab.

Seorang pegawai yang sesuai dengan bidang kerja dan profesional akan memiliki kemampuan untuk berhubungan dengan semua tingkat organisasi. Kualitas pegawai merupakan unsur pokok dalam sistem pengendalian intern yang tidak boleh diabaikan, meskipun ketiga unsur pokok sistem pengendalian intern dapat dilaksanakan cukup baik yaitu adanya struktur organisasi, sistem pemberian wewenang dan prosedur serta praktek yang sehat, namun jika dilaksanakan oleh pegawai yang kurang berkualitas dan kompeten maka pengendalian intern tidak akan berjalan dengan baik. Oleh karena itu adanya pengembangan pendidikan pegawai yang terdiri dari ikut sertanya dalam kegiatan seminar, memberikan pendidikan lebih lanjut dan mengadakan diklat dapat memperkuat dalam hal pengembangan pengawai serta secara tidak langsung dapat meningkatkan kualitas pegawai.

\section{DAFTAR PUSTAKA}

Bastian, I. (2006). Akuntansi Sektor Publik Suatu Pengantar. Jakarta: Erlangga.

Baswir, R. (2001). Akuntansi Pemerintahan Indonesia. Yogyakarta: BPFE Yogyakarta.

Caushing, B.A. (2003). Sistem Informasi Akuntansi dan Organisasi Perusahaan. Jakarta: Erlangga.

H.E.T Ruseffendi (2005). Dasar-dasar Penelitian Pendidikan dan Bidang Non Eksakta Lainya. Bandung: Tarsito

Mardiasmo. (2005). Akuntansi Sektor Publik. Jakarta: Salemba Empat.

Muhibin dan Rahayu (2009). Pembelajaran Aktif, Inovatif, Kreatif, Efektif dan Menyenangkan (PAIKEM). Fakultas Tarbiyah Universitas Islam Negeri Sunan Gunung Djati. Bandung 
Mulyadi dan Kanaka Puradireja. (2005) Auditing Suatu Pengantar. Jakarta: Salemba Empat Mulyadi. (2001). Sistem Akuntansi. Jakarta: Salemba Empat

Munandar, M. (2001). Budgeting Perencanaan Kerja, Pengkoordinasian Kerja, Pengawasan Kerja. Yogyakarta: BPFE-Yogyakarta.

Nafarin, M. (2004). Penganggaran Perusahaan. Jakarta: Salemba Empat.

Nazir. M. (2003) Metode Penelitian. Jakarta: Ghalia Indonesia

Peraturan Menteri Dalam Negeri No.13 Tahun 2006 Tentang Pengelolaan Keuangan Daerah.

Peraturan Pemerintah No.60 Tahun 2008 Tentang Sistem Pengendalian Intern Pemerintah.

Putra. I. H. (2009). Pengaruh Pembelajaran Matematika Menggunakan Pendekatan PAKEM (Pembelajaran Aktif, Kreatif, Efektif dan Menyenangkan) Terhadap Hasil Belajar Sisiwa SMP. Skripsi Jurusan Pendidikan Matematika. UNPAS Bandung: Tidak Diterbitkan

Rusman. (2010). Model-model pembelajaran, mengembangkan profesionalisme guru. Jakarta: PT. Raja Grafindo Persada.

Simanjuntak, G. (2005). Pedoman Penyusunan Anggaran Berbasis Kinerja (Revisi). http://www.bpkp.go.id/unit/sakd/abkrevisi.pdf. Diakses 3 Desember 2019.

Sjamsulbachri A. (2003) Pengantar Perencanaan Pengajaran. Bandung: Diktat Kuliah Seri Keguruan.

Sugiono. (2008) Metode Penelitian Bisnis.Bandung: Alfabeta.

Sugiono. (2010) Statistika Untuk Penelitian.Bandung: Alfabeta. 